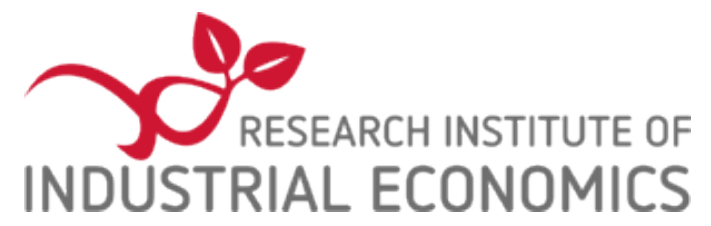

IFN Working Paper No. 1123, 2016

\title{
Job Polarization, Job Tasks and the Role of Firms
}

Fredrik Heyman 


\title{
Job polarization, job tasks and the role of firms
}

\author{
Fredrik Heyman $^{\text {p }}$
}

April 2016

\begin{abstract}
A large and growing empirical literature has presented evidence of job polarization, i.e. the simultaneous growth of high-wage jobs and low-wage jobs at the expense of middle-wage jobs. Thus far, the focus has been on employment in different occupations, without taking into account the role of firms in the labor demand process. The purpose of this paper is to bridge this knowledge gap by explicitly analyzing how firms influence the current process of job polarization. Using detailed Swedish matched employer-employee data for the 1997-2013 period, we present novel evidence on within-firm job polarization. Applying a decomposition framework, we also find that both within-firm and between-firm components are important for overall job polarization. We also show how the within-firm pattern is related to explanations for job polarization that have been proposed, i.e. the influence of routine-based technological change and the offshorability and automation of jobs. The results indicate that routineness of jobs seems to be the most important factor behind the observed pattern of within-firm job polarization.
\end{abstract}

JEL: J24, J31, O33

Keywords: Job polarization, Job tasks, Routinization, Automation, Matched employer-employee data

${ }^{\circledR}$ The Research Institute of Industrial Economics (IFN) and Lund University, Sweden. E-mail: fredrik.Heyman@ifn.se

Acknowledgements: Financial support from the Swedish Research Council for Health, Working Life and Welfare (Forte), the Torsten Söderberg Foundation and the Marianne and Marcus Wallenberg Foundation is gratefully acknowledged. Hanna Thunström provided excellent research assistance. 


\section{Introduction}

There is ongoing debate about the impact of new technology (often referred to as computerization, digitalization or use of robots) on different labor market outcomes. Fears of increasing inequality and decreasing job security, for instance due to job losses accompanied by fewer available jobs, influence the debate. There are also worries that new technology will replace not only manual routine jobs but also more advanced jobs with cognitive content. ${ }^{1}$ In a recent paper, Frey and Osborne (2013) have estimated the extent to which computerization can replace individual occupations in the US labor market. Their main result is that around half of total employment in the US is at risk of being automated within one to two decades.

An important issue in the literature that analyzes how computerization and new technology affect relative labor demand is identifying the types of workers for whom computers and new technology are a substitute and those for whom they are a complement. This in turn depends on the characteristics of individual job tasks - for instance, the routineness of job tasks. The substitution effect refers to the substitution of labor for increasingly cheap computer power. This effect is dominant in routine tasks, and thus the demand for this type of labor can be expected to be affected negatively. The substitution of human labor for computer power is, however, limited. It is in general difficult to simulate tasks that involve creativity, flexibility and good judgement. Therefore, these types of non-routine tasks will instead be complemented by increased computer usage, and the demand for this type of labor may then increase.

Several studies have showed that investments in different forms of new technology are complements to hiring employees for non-routine jobs and substitutes for hiring workers to perform routine jobs, indicating that demand for different types of labor is heterogeneous (see e.g. Autor et al. (2003; 2006), Goos and Manning (2007), Acemoglu and Autor (2011), Autor and Dorn (2009; 2013), Graetz and Michaels (2015)). These results are related to a recent, much debated phenomenon, referred to as job polarization, i.e. the simultaneous growth of high-skill, high-wage jobs and low-skill, low-wage jobs at the expense of middle-skill jobs (see e.g. Goos et al. (2014) for an overview and Asplund et al. (2011) for a cross-country analysis on the Nordic countries). Prominent explanations for this phenomenon are routine-based technological change and the offshorability and automation of jobs. ${ }^{2}$

Thus far, the substantial job polarization literature has not taken into account firms in this process. Thus, the influence of firms in the observed job polarization patterns is more or less absent in the empirical literature. The focus has instead been on employment in different occupations, with no consideration given to how firms shape the labor demand process. We aim to bridge this knowledge gap by using detailed matched firm-worker data for Sweden spanning the period 1996-2013 to investigate the

\footnotetext{
${ }^{1}$ For instance, Brynjolfsson and McAfee (2014) argue that advanced robots will soon be able to replace a broad range of job tasks. See also Autor (2015) for a recent overview on automation and employment.

2 Note that job polarization does not necessarily bring about a corresponding wage polarization (see e.g. the discussion in Autor (2015)).
} 
role played by firms in the recent trend toward a more polarized labor market. Is the polarization pattern also traceable within firms over time so that we also have within-firm job polarization?

A second purpose of this paper is to analyze the contribution of different explanations for job polarization while at the same time focusing on the role played by firms as employers. Obviously, the impact of new technology and globalization can have similar effects on firms and workers and hence on job polarization patterns. For instance, many routine job tasks are offshorable and have a potentially high risk of being automated. In addition, computerization has made it possible to offshore certain job tasks that were primarily performed by middle-skilled workers. Thus, it is difficult to separate contributions. Therefore, based on our detailed matched employer-employee data, we will analyze the interplay between computerization (automation) and globalization and how these factors shape the job polarization process within firms. It has been proposed that automation or computerization might have a role to play, but the empirical evidence is scarce. By adding computerization to the analysis, our aim is to disentangle the relative impact of the proposed explanations for job polarization, as described above.

\section{Data and descriptive statistics}

The analysis is based on register-based matched employer-employee data from Statistics Sweden covering the period 1996-2013. ${ }^{3}$ The firm data contain detailed information on all Swedish firms. The worker data cover detailed information on a representative sample of the labor force, including full-time equivalent wages, education, occupation, and gender. ${ }^{4}$ Occupations in our data are based on the Swedish Standard Classification of Occupations (SSYK96), which in turn is based on the International Standard Classification of Occupations (ISCO-88).

All data sets are matched by unique identification codes. To make the sample of firms consistent across the time periods, we restrict our analysis to firms with at least 10 employees in the non-agricultural private sector, which are available throughout the period.

As a measure of the routineness of occupations, we use the Routine Task Intensity (RTI) index, which is used in many papers on routine-based technological change (see Autor et al. (2003), Autor and Dorn (2013) and Goos et al. (2014) for more information). The offshorability of occupations is based on the same measure that is used in Goos et al. (2014), which in turn is based on Blinder and Krueger (2013). Both the RTI index and the measure of offshorability are available at the 2-digit ISCO-88 level. ${ }^{5}$

\footnotetext{
${ }^{3}$ See, e.g. Davidson et al. (2014) and Hakkala et al. (2014) for two recent articles based on the same data.

${ }^{4}$ The worker data originate from the Swedish annual salary survey (Lönestrukturstatistiken). See www.scb.se for more details on the data.

${ }^{5}$ The highest RTI index is found for office clerks and the lowest for managers of small enterprises. The measure of offshorability of occupations is highest for machine operators and assemblers and lowest for drivers and mobileplant operators.
} 
The risk of automation of jobs is based on work by Frey and Osborne (2013). They implement a novel methodology to estimate the probability of the computerization of detailed occupations. The calculated probabilities in Frey and Osborne are based on $O^{*} N E T$, which is an online service provided by the US Department of Labor. $O * N E T$ includes very detailed and in-depth information on nearly 1,000 occupations. In Frey and Osborne, occupations are classified according to the US Labor Department's Standard Occupational Classification (SOC). The estimated probabilities based on SOC have been translated into ISCO-88 to obtain figures for the occupations used in this paper. ${ }^{6}$ The highest risks for automation are found for salespeople and demonstrators and agricultural, fishery and related labourers. The lowest risks are found for legislators and senior officials and life science and health professionals.

\section{Results}

Job polarization implies that we should expect an increasing employment share for occupations in the higher and lower parts of the wage distribution and that the employment share should decrease in the middle of the wage distribution. Figure 1a) presents basic results for the entire Swedish business sector. Occupations are on the x-axis and sorted in ascending order based on average wages by occupation in 1996. The y-axis measures the change in employment shares over the period 1996-2013. To be comparable to earlier studies, we apply the same occupational classification as in Goos et al. (2009; 2014). The figure shows fairly clear patterns of job polarization in Sweden with improved employment opportunities in high-wage and low-wage occupations, while it is also apparent that a number of occupations in the middle part of the wage distribution have experienced falling employment shares during the period. In addition, the clearest pattern is observed when we study changes in employment shares over the entire period 1996-2013.

Goos et al. (2014) decompose the overall change in employment shares into within-industry and between-industry components. They show that both components are important and that overall job polarization is driven by job polarization both within and between industries. In addition to industry reallocation, we extend their analysis by addressing firms and the corresponding within-firm and between-firm components of job polarization. Results are presented in Figures 1b) and 1c). Starting with the industry components, we see that both industry components are typically positive for high-wage and low-wage occupations and that they are mostly negative for the group of middling occupations.

We have also divided occupations into three wage groups as in Goos et al. (2009; 2014). Computing the percentage point change in employment share for each of these groups, we find an increase in the high-wage group equal to 6.7 percent, a decrease in the middle-wage group equal to 17.8 percent and an increase in the low-wage group equal to 11.1 percent during the period 1996-2013. For these broad groups, we find that both industry components are positive for the high-wage and low-wage

\footnotetext{
${ }^{6}$ Details on this translation can be found in Heyman et al. (2016).
} 
groups, and for the middle-wage group, they are both negative. These results indicate that overall job polarization stems from both within- and between-industry reallocation.

Interestingly, a very similar pattern can also be seen at the firm level (Figure 1c). One difference is related to changes in employment shares for low-wage jobs. For this group, the within and between components are generally stronger at the firm level than at the industry level, suggesting that reallocation at the firm level, both within and between firms, is important for the overall rising demand for low-wage jobs. This is less clear in the industry decomposition, where several within and between components are negative, despite a strong overall growth in low-wage jobs.

Having established evidence of a polarized labor market in Sweden, we now analyze the role of firms in more detail. Can the same pattern of overall job polarization be observed within firms? This is related to the origin of changes in the employment structure. To see if we can also trace evidence of within-firm job polarization, we estimate the following equation on our panel of firms:

$$
\text { Share }_{i j t}=\alpha+\sum_{t=1997}^{2013} \delta_{t} \text { Year }_{t}+X_{i t}^{\prime} \beta+\mu_{i}+\varepsilon_{i t}
$$

where Share $_{i j t}$ is the share of workers in firm $i$ that belongs to wage group $j \in\{$ Low, Middle, High\} at time $t$. Wage groups are defined in the same way as in Goos et al. $(2009 ; 2014)$ but based on a ranking of occupations in terms of Swedish wages. Our main focus is on the estimated coefficients for $\delta_{t}$. These show over-time differences in the share of workers in the different wage groups compared with the base year 1996. Equation (1) is estimated separately for each group's share of employment in the firms. We also include a vector $X$ of time-varying firm characteristics that might affect the different employment shares. These characteristics include log value added per employee and log capital intensity. All of the estimations also include firm fixed effects $\mu_{i}$ to control for unobserved firm heterogeneity. Thus, all variation over time in the relative demand for the different groups of occupations originates from withinfirm variation. Finally, $\varepsilon_{j t}$ is the error term. To allow for within-firm correlation over time, standard errors are adjusted for clustering at the firm level.

Results are presented in Figure 2. The figure plots the estimated coefficients for $\delta_{t}$ for the different wage groups. ${ }^{7}$ Here, we find an increasing trend in the share of employees in the high-wage group, while at the same time, the share of middle-wage group workers decreases within firms over time. We notice an increase in the high-wage group of about 5 percentage points over the period 1996-2013. The share of middle-wage employees decreases by approximately the same amount. These two developments are consistent with within-firm job polarization. However, we find no support for an increasing share of low-wage jobs within firms over the period. We note, however, a few years with positive and statistically significant estimated coefficients that are in accordance with a positive development for this wage group. We also see that the estimated coefficients are consistently positive

\footnotetext{
${ }^{7}$ The exact estimates are available upon request.
} 
during the period for the low-wage group. Overall, the evidence in Table 1 points to a divergence in employment opportunities across occupations at different parts of the wage distribution over the period.

A similar pattern can also be seen when we study different time periods. Columns $1-3$ in Table 1 present results for four different time periods. The last three columns split the entire period into two periods, comparing 1996-2004 with 2005-2013. Regardless of how we look at the development in relative demand for different occupations over time, we find evidence for job polarization with an increasing magnitude in the final years of our sample period.

\section{Impact of routine-based technological change, offshoring and automation of jobs}

We now turn to analyzing how the observed pattern of within-firm job polarization is related to three prominent explanations for job polarization, namely, the influence of routine-based technological change, and the offshorability and automation of jobs. ${ }^{8}$ Goos et al. (2014) use data on 16 Western European countries and find that routine-based technological change is more important than offshoring in explaining the pattern of polarization across countries.

In addition to the hypotheses that recent routine-based technological change and increased opportunities for offshoring explain job polarization, as set forth in Goos et al. (2014), we are also able to use a new measure of the risk of job automation and to determine how this is related to job polarization. It is of course important to keep in mind that the different explanations interact, and thus it is difficult to precisely disentangle the influence from each explanation. Many of the same arguments on how new technology influences different occupations can also be applied to the impact of international trade and offshoring. For instance, job tasks that are "routine" from an automation standpoint might also be accomplished at a foreign location.

We start by looking at the impact of routineness of jobs, defined in terms of the RTI index described above. The results are presented in panel a) in Table 2. To see how RTI influences within-firm job polarization, we first divide firms into two groups according to the intensity of routineness for the firm's workforce in their initial year. We then estimate separate regressions on each wage group and on each group according to the intensity of routineness. The basis for this exercise is that firms with a high initial share of routine workers have more opportunities over time to reallocate their workforce in favor of more non-routine jobs, compared to firms that initially have low shares of routine jobs (i.e. an initial high share of non-routine workers). Columns (1), (3) and (5) show estimations for the group of firms with high

\footnotetext{
${ }^{8}$ While it is difficult to obtain causal evidence on the separate impact of routineness of jobs, offshoring and automation of jobs, our aim in this final section is to analyze how differences in the firm's workforce in terms of these characteristics are related to job polarization
} 
initial average routineness. The corresponding regressions on low routineness firms are presented in columns (2), (4) and (6). ${ }^{9}$

The results are clear: The pattern presented in Figure 2 showing evidence on within-firm job polarization originates from firms with high initial routineness among the workforce. These are firms that have more opportunities to switch to a composition of employees with less routine job tasks compared to firms with a low initial share of routine workers. Comparing columns (1) and (2), we note that the increase in employment for the high-wage group stems from firms that can initially be characterized as high-routine. The same is also the case for demand for low-wage jobs in high-routine firms (column (6)). For these firms, we observe a clear increase in employment for low-wage occupations. These results, in combination with decreasing demand for middle-wage workers in firms with high initial average routineness (column (4)), are consistent with routine-biased technological change as an explanation for job polarization. If we instead study firms with low initial average routineness, no job polarization can be seen. For these firms, the opposite development is observed - increasing demand for middle-wage workers in combination with lower demand for the low-wage group and a tendency for lower over-time demand for high-wage occupations.

Instead of focusing on initial levels of the degree of routineness, columns (7) to (12) divide firms by the change in the RTI index over time. Firms are divided into two groups according to whether they have experienced an increase or decrease in average routineness over the sample period. Consistent with the results for initial levels of the degree of routineness, the results in this case indicate that the job polarization pattern originates from firms with decreasing use of routine jobs (or, alternatively stated, from firms with increasing relative demand for non-routine jobs). For these firms, we observe job polarization in accordance with routine-biased technological change.

Overall, the results in panel a) in Table 2 indicate that the initial composition of the workforce in terms of the degree of routineness and its change over time is systematically related to the observed pattern of within-firm job polarization. The shift away in demand for jobs that are more routine-intensive does seem to bring about a change in firms' occupational distribution. Next, we study how offshorability is related to within-firm job polarization (see panel b). Based on the same approach as that for routineness, we now take into account firms' initial occupational structure in terms of the offshorability of occupations to see how this is associated with the relative demand for the three wage groups. According to panel b) in Table 2, differences in offshorability among the firms' workforce is not systematically related to job polarization. Regardless of how we divide firms in terms of offshorability, no differences according to job polarization can be traced. The only exception is for low-wage workers, but overall, firm

\footnotetext{
${ }^{9}$ For brevity, the table show results for four time periods, but the results are qualitatively the same when we, for instance, estimate on individual year dummies (results available upon request).
} 
differences in the composition of the workforce in terms of offshorability are not systematically related to within-firm job polarization.

A similar pattern can be seen for automation risks for occupations. The results are presented in panel c). Regardless of how firms are classified in terms of the average risk of workforce automation, no systematic pattern in terms of job polarization can be observed. Given the closeness between an occupation's routineness and its risk of being automated, we have also analyzed combinations of routineness and automation risks. For these combinations, we find that the initial composition of the workforce in terms of the degree of routineness and its change over time is more important than the corresponding classification of firms in terms of automation risks. ${ }^{10}$ The same pattern also emerges when we study combinations of firms' workforce in terms of routineness and offshorability. These unreported results again suggest that routine-biased technological change is an important explanation for job polarization.

\section{Concluding remarks}

This paper relates to a large and growing literature that has documented evidence of job polarization. The role played by firms is, however, more or less absent in this literature. This paper bridges this knowledge gap by using matched firm-worker data to analyze the role played by firms in the recent development of a more polarized labor market. Our results show novel evidence of within-firm job polarization, indicating that the observed economy-wide pattern is also present over time within firms. We also find that both the within-firm and between-firm components are important in explaining overall job polarization. This new evidence adds to previous work by Goos et al. (2014), who show that overall job polarization is driven by job polarization both within and between industries. With our matched firmworker data, we are also able to show that the firm components are important.

A second purpose of this paper is to study the contribution of different explanations for job polarization while at the same time focusing on the role played by firms as employers. In addition to taking into account how routineness and offshorability of occupation influence the job polarization process, we are also able to study the role played by automation or computerization. Results indicate that the degree of routineness is the most important explanation for the observed within-firm pattern. This is consistent with the analysis in Goos et al. (2014) at the industry-country level, which indicates that routine-biased technological change is more important than offshoring in explaining job polarization. Bringing the analysis down to the firm level seems to confirm the important role played by routine-biased technological change.

\footnotetext{
$\overline{{ }^{10} \text { Results are available upon request. }}$
} 


\section{References}

Acemoglu, Daron and David H. Autor (2011), "Skills, Tasks and Technologies: Implications for Employment and Earnings," in Handbook of Labor Economics, Volume 4, Part B, Orley Ashenfelter and David E. Card (eds.), Amsterdam: Elsevier.

Asplund, R., E. Barth, P. Lundborg and K. Misje Nilsen (2011), "Polarization of the Nordic Labor Markets", Finish Economic Papers, 24(2), 87-110.

Autor, D. (2015), "Why Are There Still So Many Jobs? The History and Future of Workplace Automation”, Journal of Economic Perspectives, Summer 2015, 3-30.

Autor, D. and D. Dorn (2009), "This Job is "Getting Old": Measuring Changes in Job Opportunities using Occupational Age Structure” American Economic Review, 99(2), 45-51.

Autor, D. and D. Dorn (2013), "The Growth of Low-Skill Service Jobs and the Polarization of the U.S. Labor Market”, American Economic Review, 103(5), 1553-1597.

Autor, D., R. J. Murnane and F. Levy (2003), “The Skill Content of Recent Technological Change: An Empirical Exploration", Quarterly Journal of Economics, 118(4), 1279-1334.

Autor, D., L. F. Katz and M. S. Kearney (2006), "The Polarization of the U.S. Labor Market", American Economic Review Papers and Proceedings, 96(2), 189-194.

Blinder, A. S. and A. B. Krueger (2013), "Alternative Measures of Offshorability: A Survey Approach", Journal of Labor Economics, University of Chicago Press, 31(1), 97-128.

Brynjolfsson, E., and A. McAfee (2014), The Second Machine Age: Work, Progress and Prosperity in a Time of Brilliant Technologies, New York: Norton \& Company.

Frey, C.B and A.M. Osborne (2013), "The future of Employment, How Susceptible are jobs to Computerization?", Oxford Martin School Working Paper.

Davidson, C., F. Heyman, S. Matusz, F. Sjöholm and S. Chun Zhu (2014). 'Globalization and imperfect labor market sorting', Journal of International Economics, 94(2), 177-194.

Goos, M. and A. Manning, (2007), "Lousy and Lovely Jobs: The Rising Polarization of Work in Britain" The Review of Economics and Statistics, 89(1), 118-133.

Goos, M., A. Manning and A. Salomons (2009), "Job Polarization in Europe", American Economic Review: Papers \& Proceedings, 99(2), 58-63.

Goos, M., A. Manning and A. Salomons (2014), "Explaining Job Polarization: Routine-Biased Technological Change and Offshoring", American Economic Review, 104(8), 2509-2526.

Graetz G. and G. Michaels (2015), "Robots at work", CEP Discussion paper No 1335.

Hakkala, K., F. Heyman and F. Sjöholm (2014), 'Multinational firms and job tasks', European Economic Review, 66, 248-265.

Heyman, F., P-J. Norbäck and L. Persson (2016), Digitaliseringen och strukturomvandlingen i svenskt näringsliv: teori, empiri och policy ("Digitalization and structural change in the Swedish business sector: theory, empirics and policy", Govermental report to Expertgruppen för offentlig ekonomi (ESO), forthcoming 2016. 
Fig. 1a: Job Polarization in Sweden 1996-2013.

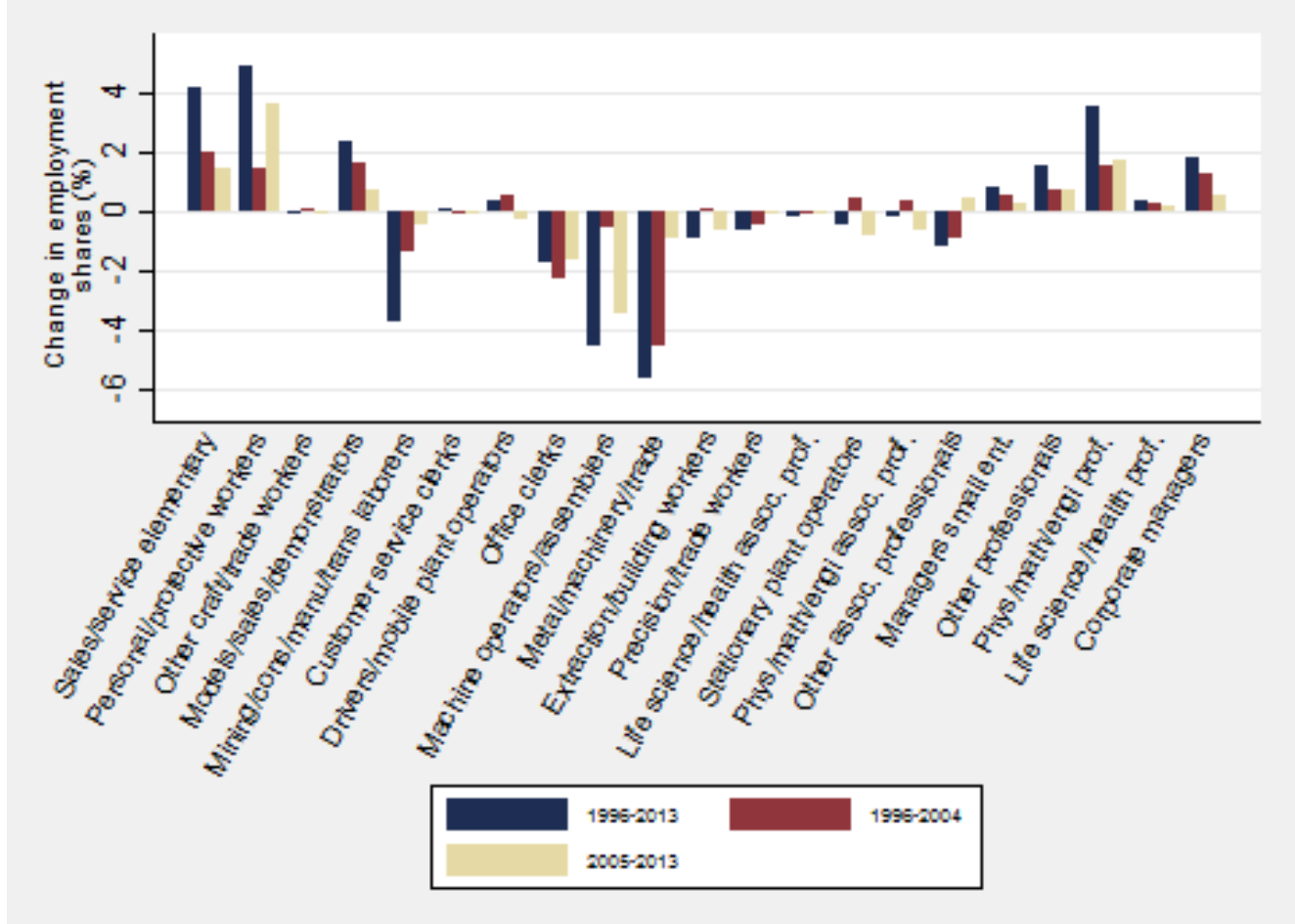

Note: The figure shows changes in employment shares for different periods. Occupations are based on ISCO-88 and are ordered by their mean wage in the first year (1996).

Fig. 1b) Changes in employment shares 1996-2013: Within and between industries.

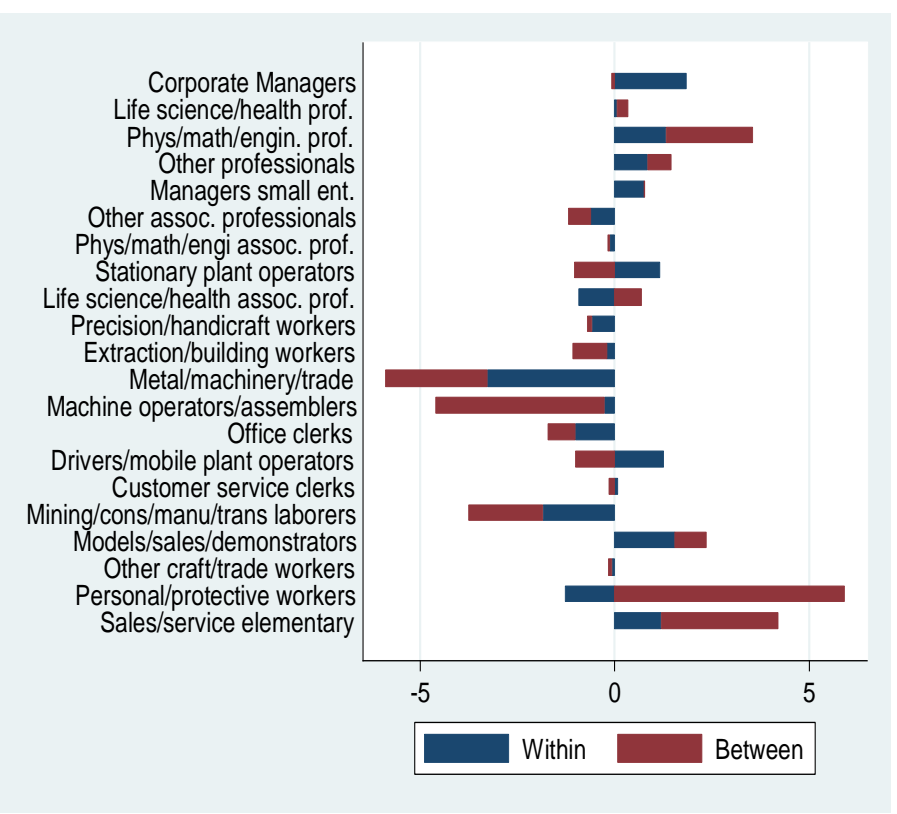

Fig. 1c) Changes in employment shares 1996-2013: Within and between firms.

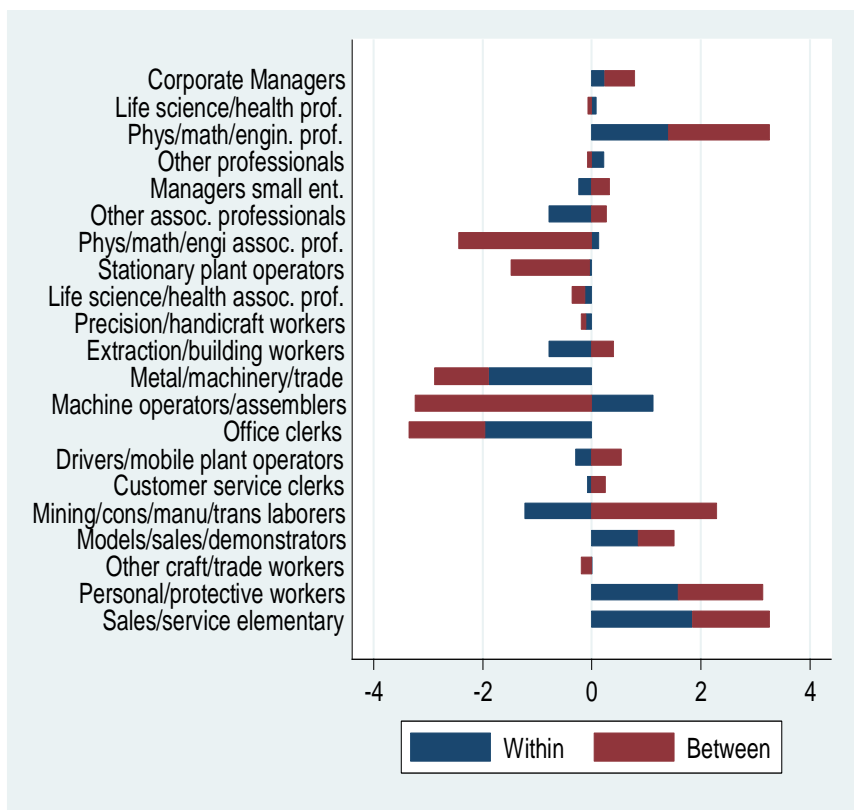

Note: The figures show decompositions of changes in employment shares for 1996-2013. Occupations are based on ISCO-88 and are ordered by their mean wage in the first year (1996). Each bar represents percentage point changes in employment shares between 1996 and 2013. Fig. 1b) illustrates the within- and between-industry components of the overall pattern for 1996-2013 presented in Fig. 1a). For occupations with one positive and one negative component, the sum adds up to the overall change seen in Fig. 1a). Fig. 1c) illustrates the within- and between-firm components. These are based on using the earliest and latest years of data for each firm for firms that do not exist for the whole period of study, 1996 through 2013. 
Fig. 2: Job polarization in Sweden 1996-2013. Estimated coefficients on occupation group-year dummies.

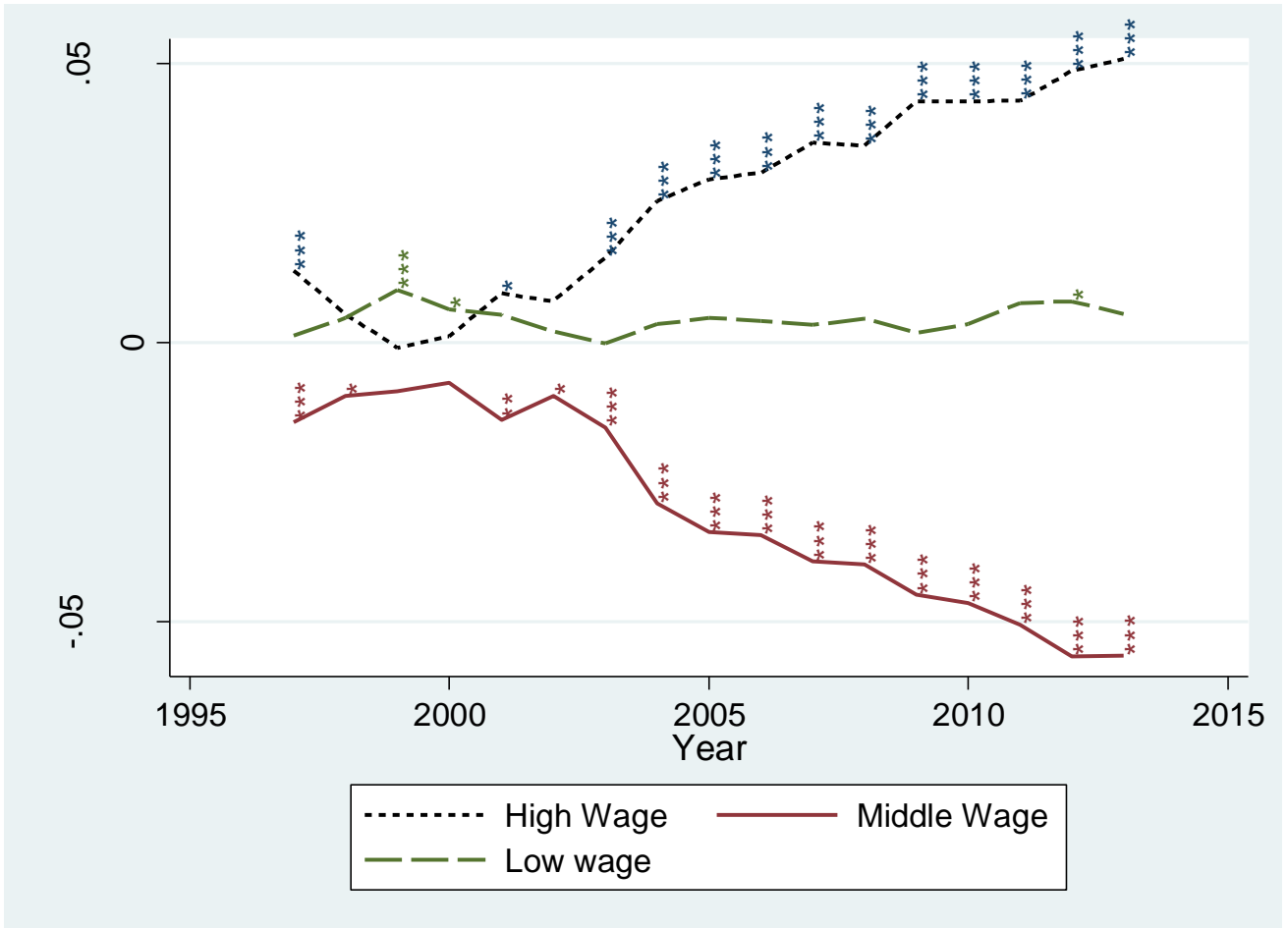

Note: The figure plots estimated coefficients on $\delta_{t}$ obtained from equation (1). Stars denote the level at which the estimated coefficients are significantly different from zero. Standard errors are clustered by firm. ***, **, * show significance at the $1 \%, 5 \%$, and $10 \%$ level, respectively.

Table 1: Job polarization at the firm level. Firm-level regressions 1996-2013.
(1)
(2)
(3)
(4)

(5)

(6)

High wage group Middle wage group Low wage group High wage group Middle wage group Low wage group

$\begin{array}{cccc}\text { D_1999-2003 } & -0.001 & -0.002 & 0.003 \\ & (0.003) & (0.003) & (0.002) \\ \text { D_2004-2008 } & 0.022^{* * *} & -0.025^{* * *} & 0.003 \\ & (0.004) & (0.004) & (0.003) \\ \text { D_2009-2013 } & 0.035^{* * *} & -0.039^{* * *} & 0.003 \\ & (0.004) & (0.005) & (0.003)\end{array}$

D_2005-2013

$\begin{array}{cc}0.025 * * * & -0.026 * * * \\ (0.003) & (0.003)\end{array}$

\begin{tabular}{lcccccc} 
Firm controls & YES & YES & YES & YES & YES & YES \\
Firm FE & YES & YES & YES & YES & YES & YES \\
Observations & 69,099 & 69,099 & 69,099 & 69,099 & 69,099 & 69,099 \\
R-squared & 0.010 & 0.010 & 0.000 & 0.008 & 0.007 & 0.000 \\
\hline
\end{tabular}

Note: The dependent variable is the share of high-, medium- and low-wage employees at the firm level. Columns 1-3 present results for four different periods (the initial period 1996-1998 and 1999-2003, 2004-2008 and 2009-2013). Columns 4-6 split the entire period into two, comparing 19962004 with 2005-2013. Firm controls include the log of value added per employee and the log of the capital-labor ratio. Firm and year fixed effects are included in all estimations. Standard errors are clustered by firm. ***, **, * show significance at the 1\%, 5\%, and $10 \%$ level, respectively. 
Table 2: Routineness, automation, offshoring and job polarization at the firm level. Firm-level regressions $1996-2013$.

\begin{tabular}{|c|c|c|c|c|c|c|c|c|c|c|c|c|}
\hline & $\begin{array}{l}\quad(1) \\
\text { High wage } \\
\text { group }\end{array}$ & $\begin{array}{l}\text { (2) } \\
\text { High wage } \\
\text { group }\end{array}$ & $\begin{array}{c}\text { (3) } \\
\text { Middle } \\
\text { wage group }\end{array}$ & $\begin{array}{c}\text { (4) } \\
\text { Middle } \\
\text { wage group } \\
\end{array}$ & $\begin{array}{c}\text { (5) } \\
\text { Low wage } \\
\text { group }\end{array}$ & $\begin{array}{c}\text { (6) } \\
\text { Low wage } \\
\text { group }\end{array}$ & $\begin{array}{l}\text { (7) } \\
\text { High wage } \\
\text { group }\end{array}$ & $\begin{array}{c}(8) \\
\text { High wage } \\
\text { group }\end{array}$ & $\begin{array}{c}\text { (9) } \\
\text { Middle } \\
\text { wage group } \\
\end{array}$ & $\begin{array}{c}(10) \\
\text { Middle } \\
\text { wage group } \\
\end{array}$ & $\begin{array}{c}(11) \\
\text { Low wage } \\
\text { group }\end{array}$ & $\begin{array}{c}(12) \\
\text { Low wage } \\
\text { group }\end{array}$ \\
\hline & Low: & High: & Low: & High: & Low: & High: & $\begin{array}{l}\text { Positive } \\
\text { change: }\end{array}$ & $\begin{array}{l}\text { Negative } \\
\text { change: }\end{array}$ & $\begin{array}{l}\text { Positive } \\
\text { change: }\end{array}$ & $\begin{array}{l}\text { Negative } \\
\text { change: }\end{array}$ & $\begin{array}{l}\text { Positive } \\
\text { change: }\end{array}$ & $\begin{array}{l}\text { Negative } \\
\text { change: }\end{array}$ \\
\hline Panel a: Routineness & & & & & & & & & & & & \\
\hline D_1999-2003 & $\begin{array}{c}-0.012 * * * \\
(0.005)\end{array}$ & $\begin{array}{c}0.006 \\
(0.004)\end{array}$ & $\begin{array}{c}0.014 * * * \\
(0.005)\end{array}$ & $\begin{array}{c}-0.011 * * * \\
(0.004)\end{array}$ & $\begin{array}{c}-0.002 \\
(0.004)\end{array}$ & $\begin{array}{l}0.006^{*} \\
(0.003)\end{array}$ & $\begin{array}{c}-0.030^{* * *} \\
(0.005)\end{array}$ & $\begin{array}{c}0.020 * * * \\
(0.004)\end{array}$ & $\begin{array}{c}0.026 * * * \\
(0.005)\end{array}$ & $\begin{array}{c}-0.022 * * * \\
(0.004)\end{array}$ & $\begin{array}{c}0.004 \\
(0.003)\end{array}$ & $\begin{array}{c}0.002 \\
(0.003)\end{array}$ \\
\hline D_2004-2008 & $\begin{array}{c}-0.010^{*} \\
(0.006)\end{array}$ & $\begin{array}{c}0.042 * * * \\
(0.005)\end{array}$ & $\begin{array}{c}0.023 * * * \\
(0.006)\end{array}$ & $\begin{array}{c}-0.056^{* * * *} \\
(0.006)\end{array}$ & $\begin{array}{c}-0.013 * * \\
(0.005)\end{array}$ & $\begin{array}{c}0.014 * * * \\
(0.004)\end{array}$ & $\begin{array}{c}-0.043 * * * \\
(0.006)\end{array}$ & $\begin{array}{c}0.069 * * * \\
(0.005)\end{array}$ & $\begin{array}{c}0.041 * * * \\
(0.007)\end{array}$ & $\begin{array}{c}-0.073 * * * \\
(0.005)\end{array}$ & $\begin{array}{c}0.002 \\
(0.005)\end{array}$ & $\begin{array}{c}0.004 \\
(0.004)\end{array}$ \\
\hline D_2009-2013 & $\begin{array}{l}-0.007 \\
(0.007)\end{array}$ & $\begin{array}{c}0.064 * * * \\
(0.006)\end{array}$ & $\begin{array}{c}0.020 * * * \\
(0.007)\end{array}$ & $\begin{array}{c}-0.078 * * * \\
(0.006)\end{array}$ & $\begin{array}{c}-0.013 * * \\
(0.006)\end{array}$ & $\begin{array}{c}0.014 * * * \\
(0.004)\end{array}$ & $\begin{array}{c}-0.057 * * * \\
(0.007)\end{array}$ & $\begin{array}{c}0.102 * * * \\
(0.005)\end{array}$ & $\begin{array}{c}0.055^{* * * *} \\
(0.007)\end{array}$ & $\begin{array}{c}-0.106 * * * \\
(0.006)\end{array}$ & $\begin{array}{c}0.002 \\
(0.006)\end{array}$ & $\begin{array}{c}0.004 \\
(0.004)\end{array}$ \\
\hline Panel b: Offshoring & & & & & & & & & & & & \\
\hline D_1999-2003 & $\begin{array}{c}0.008 * * \\
(0.004)\end{array}$ & $\begin{array}{c}-0.008^{*} \\
(0.004)\end{array}$ & $\begin{array}{c}-0.008^{*} \\
(0.005)\end{array}$ & $\begin{array}{c}0.004 \\
(0.005)\end{array}$ & $\begin{array}{c}0.000 \\
(0.004)\end{array}$ & $\begin{array}{c}0.005^{* *} \\
(0.002)\end{array}$ & $\begin{array}{c}0.005 \\
(0.004)\end{array}$ & $\begin{array}{c}-0.007 \\
(0.004)\end{array}$ & $\begin{array}{l}0.009 * \\
(0.005)\end{array}$ & $\begin{array}{c}-0.012 * * \\
(0.005)\end{array}$ & $\begin{array}{c}-0.014 * * * \\
(0.003)\end{array}$ & $\begin{array}{c}0.019 * * * \\
(0.003)\end{array}$ \\
\hline D_2004-2008 & $\begin{array}{c}0.020 * * * \\
(0.005)\end{array}$ & $\begin{array}{c}0.023 * * * \\
(0.005)\end{array}$ & $\begin{array}{c}-0.013 * * \\
(0.006)\end{array}$ & $\begin{array}{c}-0.034 * * * \\
(0.006)\end{array}$ & $\begin{array}{c}-0.007 \\
(0.006)\end{array}$ & $\begin{array}{c}0.011 * * * \\
(0.003)\end{array}$ & $\begin{array}{c}0.024 * * * \\
(0.005)\end{array}$ & $\begin{array}{c}0.020 * * * \\
(0.006)\end{array}$ & $\begin{array}{l}0.010 * \\
(0.006)\end{array}$ & $\begin{array}{c}-0.058 * * * \\
(0.006)\end{array}$ & $\begin{array}{c}-0.035^{* * *} \\
(0.004)\end{array}$ & $\begin{array}{c}0.039 * * * \\
(0.004)\end{array}$ \\
\hline D_2009-2013 & $\begin{array}{c}0.033 * * * \\
(0.006)\end{array}$ & $\begin{array}{c}0.036^{* * * *} \\
(0.006)\end{array}$ & $\begin{array}{c}-0.024 * * * \\
(0.007)\end{array}$ & $\begin{array}{c}-0.049 * * * \\
(0.006)\end{array}$ & $\begin{array}{l}-0.009 \\
(0.007)\end{array}$ & $\begin{array}{c}0.012 * * * \\
(0.003)\end{array}$ & $\begin{array}{c}0.042 * * * \\
(0.006)\end{array}$ & $\begin{array}{c}0.030 * * * \\
(0.006)\end{array}$ & $\begin{array}{c}0.004 \\
(0.007)\end{array}$ & $\begin{array}{c}-0.079 * * * \\
(0.007)\end{array}$ & $\begin{array}{c}-0.045^{* * *} \\
(0.005)\end{array}$ & $\begin{array}{c}0.049 * * * \\
(0.005)\end{array}$ \\
\hline Panel c: Automation & & & & & & & & & & & & \\
\hline D_1999-2003 & $\begin{array}{c}0.003 \\
(0.005)\end{array}$ & $\begin{array}{l}-0.004 \\
(0.004)\end{array}$ & $\begin{array}{l}-0.006 \\
(0.005)\end{array}$ & $\begin{array}{c}0.002 \\
(0.005)\end{array}$ & $\begin{array}{c}0.004 \\
(0.003)\end{array}$ & $\begin{array}{c}0.002 \\
(0.003)\end{array}$ & $\begin{array}{c}-0.036^{* * *} \\
(0.006)\end{array}$ & $\begin{array}{c}0.021 * * * \\
(0.003)\end{array}$ & $\begin{array}{c}0.025 * * * \\
(0.006)\end{array}$ & $\begin{array}{c}-0.019 * * * \\
(0.004)\end{array}$ & $\begin{array}{c}0.011^{* * * *} \\
(0.004)\end{array}$ & $\begin{array}{c}-0.002 \\
(0.003)\end{array}$ \\
\hline D_2004-2008 & $\begin{array}{c}0.021 * * * \\
(0.006)\end{array}$ & $\begin{array}{c}0.023 * * * \\
(0.005)\end{array}$ & $\begin{array}{c}-0.025^{* * *} \\
(0.006)\end{array}$ & $\begin{array}{c}-0.026 * * * \\
(0.006)\end{array}$ & $\begin{array}{c}0.004 \\
(0.003)\end{array}$ & $\begin{array}{c}0.003 \\
(0.005)\end{array}$ & $\begin{array}{c}-0.042 * * * \\
(0.007)\end{array}$ & $\begin{array}{c}0.063 * * * \\
(0.005)\end{array}$ & $\begin{array}{c}0.020 * * * \\
(0.007)\end{array}$ & $\begin{array}{c}-0.054 * * * \\
(0.005)\end{array}$ & $\begin{array}{c}0.022 * * * \\
(0.005)\end{array}$ & $\begin{array}{c}-0.009 * * \\
(0.004)\end{array}$ \\
\hline D_2009-2013 & $\begin{array}{c}0.031 * * * \\
(0.007)\end{array}$ & $\begin{array}{c}0.039 * * * \\
(0.006)\end{array}$ & $\begin{array}{c}-0.035 * * * \\
(0.006)\end{array}$ & $\begin{array}{c}-0.043 * * * \\
(0.007)\end{array}$ & $\begin{array}{c}0.004 \\
(0.004)\end{array}$ & $\begin{array}{c}0.003 \\
(0.006)\end{array}$ & $\begin{array}{c}-0.051 * * * \\
(0.007)\end{array}$ & $\begin{array}{c}0.093 * * * \\
(0.005)\end{array}$ & $\begin{array}{c}0.022 * * * \\
(0.008)\end{array}$ & $\begin{array}{c}-0.080 * * * \\
(0.006)\end{array}$ & $\begin{array}{c}0.029 * * * \\
(0.005)\end{array}$ & $\begin{array}{c}-0.013 * * * \\
(0.004)\end{array}$ \\
\hline Firm controls & YES & YES & YES & YES & YES & YES & YES & YES & YES & YES & YES & YES \\
\hline Firm FE & YES & YES & YES & YES & YES & YES & YES & YES & YES & YES & YES & YES \\
\hline
\end{tabular}

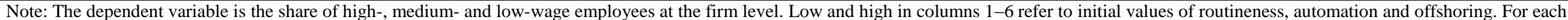

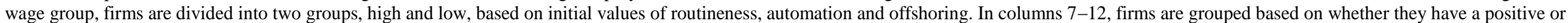

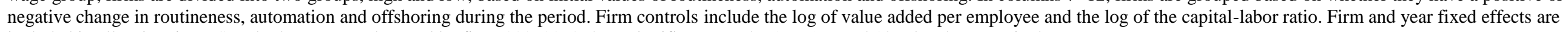
included in all estimations. Standard errors are clustered by firm. $* * *, * * *$ show significance at the $1 \%, 5 \%$, and $10 \%$ level, respectively. 